\title{
Ruch biblijny i liturgiczny
}

\section{O. Franciszek Małaczyński OSB, Tyniec}

\section{NOWY ETAP ODRODZENIA LITURGII}

Liturgia, jako kult oddawany Bogu przez widzialną społeczność, musi mieć swoje przepisy określające sposób wykonywania czynności liturgicznych. Przepisy te, zwane ,rubrykami“ od barwy druku wyróżniającej je wśród tekstów liturgicznych, od dawna wymagały grutownej reformy.

Sytuacja w dziedzinie rubryk przypominała położenie w dziedzinie prawa kościelnego przed jego kodyfikacją. Przez wieki nawarstwiały się rozporządzenia papieskie i odpowiedzi Sw. Kongregacji Obrzędów tak, że powstał gasscz przepisów, w których nawet najbieglejsi nie zawsze mogli się wyznać.

Potrzebie reformy usiłował zaradzić Fius XII przez dekret Sw. Kongregacji Obrzędów O uproszczeniu rubryk z 23 marca 1955 r. Dekret ten, już w założeniach swoich prowizoryczny, wywołał tym goretsze pragnienie uporządkowania całej dziedziny rubryk. Biorąc jednak pod uwagę zamierzoną ogólną reformę ksiąg liturgicznych i zapowiedziane zwołanie Soboru powszechnego nie spodziewaliśmy się przed Soborem nowych aktów prawodawczych w tej dziedzinie. Tymczasem 10 numer Acta Apostolicae Sedis z datą 15 sierpnia 1960 r. przyniósł nowy zbiór rubryk, zatwierdzony przez Ojca św. Jana XXIII dnia 25 lipca 1960 r. i ogłoszony nastepnego dnia przez św. Kongregację Obrzędów. Nowy kodeks rubryk jest zatem niespodzianką, kłopotliwą wprawdzie dla autorów kalendarzy 
kościelnych, ale miłą dla sprawujących liturgię i jej uczestników.

Kodyfikacja rubryk mszału i brewiarza stanowi nowy poważny etap $\mathrm{w}$ dziedzinie odrodzenia liturgii, nie jest to jednak etap ostateczny. Papież zostawia Ojcom przyszłego Soboru rozpatrzenie podstawowych zasad reformy liturgii i decyzje co do zmiany tekstów liturgicznych. Wiadomo również, że komisje papieskie od lat pracują nad nowym przekładem Psałterza i rozłożeniem go $\mathrm{w}$ Brewiarzu, że przewiduje się nowy rozkład perykop z Pisma św. we Mszy i w Oficjum, a nawet pewne zmiany $w$ ich strukturze. Niemniej nowy kodeks będzie przez dłuższy czas normował służbę Bożą w Kościele łacińskim.

Ponieważ z dniem 1 stycznia $1961 \mathrm{r}$. tracą moc rubryki ogólne Brewiarza i Mszału rzymskiego, a także wszystkie odpowiedzi św. Kongregacji Obrzędów sprzeczne z nowym Kodeksem rubryk, postanowiliśmy podać naszym czytelnikom w całości nowy zbiór rubryk oraz związane $\mathrm{z}$ nim dokumenty Stolicy Swiętej w polskim przekładzie.

Tłumacząc nowy zbiór rubryk starałem się unikać „,̇argonu" jaki spotyka się niekiedy $\mathrm{w}$ dziedzinie rubrycystyki (np. „w razie konkurencji komemoruje się ferię"). Dlatego starałem się używać określeń polskich, a tam gdzie nie ma utartego terminu w języku polskim pozostawiłem wyraz łaciński. W. nawiasach podałem charakterystyczne określenia i zwroty łacińskie. W języku oryginalnym podaję również kalendarz, którego zrozumienie nie nastręcza trudności.

Ponieważ z konieczności tłumaczyłem szybko, na pewno przekład nie jest wolny od usterek. $\mathrm{Z}$ wdzięcznością przyjmę uwagi czytelników i propozycje co do polskiej terminologii w dziedzinie rubrycystyki.

O. FRANCISZEK MAEACZYŃSKI OSB

Tłumacz zastrzega sobie wszelkie prawa do przekładów zawartych w tym numerze. 